\title{
Technological and antioxidant characteristics of pasta with whole wheat flour and
}

\section{natural colored concentrates}

\author{
Características tecnológicas e antioxidantes de massa alimentícia com farinha de trigo de grão
}

inteiro e concentrados coloridos naturais

Características tecnológicas y antioxidantes de la pasta con harina de trigo integral y concentrados

de color naturales

Received: 02/18/2021 | Reviewed: 02/25/2021 | Accept: 02/26/2021 | Published: 03/06/2021

\author{
Adriana Lucia Wahanik \\ ORCID: https://orcid.org/0000-0002-8999-558X \\ Universidade Estadual de Campinas, Brazil \\ E-mail: alwahanikd@gmail.com \\ Iramaia Angélica Neri-Numa \\ ORCID: https://orcid.org/0000-0002-2151-417X \\ Universidade Estadual de Campinas, Brazil \\ E-mail: iramaianuma@gmail.com \\ Glaucia Maria Pastore \\ ORCID: https://orcid.org/0000-0001-9631-0158 \\ Universidade Estadual de Campinas, Brazil \\ E-mail: glaupast@fea.unicamp.br \\ Mária Herminia Ferrari Felisberto \\ ORCID: https://orcid.org/0000-0003-1538-7941 \\ Universidade Federal de Viçosa, Brazil \\ E-mail: maria.felisberto@ufv.br \\ Pedro Henrique Campelo \\ ORCID: https://orcid.org/0000-0002-4048-3858 \\ Universidade Federal do Amazonas, Brazil \\ E-mail: pedrocampelo@ufam.edu.br \\ Maria Teresa Pedrosa Silva Clerici \\ ORCID: https://orcid.org/0000-0002-8445-336X \\ Universidade Estadual de Campinas, Brazil \\ E-mail: mclerici@unicamp.br
}

\begin{abstract}
Whole wheat pasta is rich in fiber and antioxidants, but presents dark color and altered cooking characteristics. This study aimed to evaluate the effects of yellow (YNC) and pink (PNC) natural concentrates in fresh whole wheat pasta, on its fiber content, and technological, and antioxidant properties. Control pasta (CP) was prepared (70:30 w:w whole grain wheat (WGF): refined wheat flour (RWF)). YNC and PNC were applied (1 to $2 \mathrm{~g} / 100 \mathrm{~g}$ ) in pastas containing 60 to $70 \mathrm{~g} / 100 \mathrm{~g}$ of WGF, following a 22 experimental design, with three central points. YNC and PNC modified whole wheat pastas color, without altering their technological characteristics. Yellow pasta (YP1, 60:40 WGF:RWF w:w, $1 \mathrm{~g}$ YNC/100 g) and pink pasta (PP9, 70:30 WGF:RWF w:w, $1 \mathrm{~g} \mathrm{PNC/100} \mathrm{g)} \mathrm{presented} \mathrm{similar} \mathrm{texture,} \mathrm{weight} \mathrm{gain} \mathrm{and}$ cooking loss to CP, and they were selected for antioxidants analysis. The three pastas had high fiber content (above 6 $\mathrm{g} / 100 \mathrm{~g}$ ), and PNC caused a significant increase in total phenolics content in raw and cooked whole wheat pasta. The natural-colored concentrates are an alternative for modifying the color of whole wheat pasta while adding functional value to it.
\end{abstract}

Keywords: Whole pasta; Natural colored; Antioxidant; Healthiness.

\section{Resumo}

A massa alimentícia contendo farinha de grão inteiro é rica em fibra e antioxidantes, mas apresenta cor escura e características de cozimento alteradas. Esse estudo objetivou avaliar os efeitos dos concentrados naturais coloridos amarelo (YNC) e rosa (PNC) em massa fresca contendo farinha de trigo de grão inteiro, no conteúdo de fibra, e propriedades tecnológicas e antioxidantes. Foi usada massa controle (CP) (70:30 w:w farinha de trigo de grão inteiro (WGF): farinha de trigo refinada (RWF)) para comparação com as demais massas que tiveram YNC e PNC em concentrações de 1a $2 \mathrm{~g} / 100 \mathrm{~g}$ ) em massas contendo de 60 a $70 \mathrm{~g} / 100 \mathrm{~g}$ de WGF, usando um delineamento linear fatorial 22 , com três pontos centrais. YNC e PNC modificaram a cor das massas de grão inteiro, sem alterar suas características tecnológicas. A massa amarela (YP1, 60:40 WGF:RWF w:w, $1 \mathrm{~g}$ YNC/100 g) e massa rosa (PP9, 70:30 WGF:RWF 
w:w, $1 \mathrm{~g} \mathrm{PNC/100} \mathrm{g)} \mathrm{apresentaram} \mathrm{textura,} \mathrm{aumento} \mathrm{de} \mathrm{peso} \mathrm{e} \mathrm{perda} \mathrm{de} \mathrm{sólidos} \mathrm{semelhantes} \mathrm{a} \mathrm{CP,} \mathrm{e} \mathrm{foram} \mathrm{selecionadas}$ para análise de antioxidantes. As três massas tiveram conteúdo de fibra alimentar superior a $6 \%$, e PNC causou um incremento significativo nos fenólicos totais nas massas crua e cozida. Os concentrados naturais coloridos foram usados em quantidades abaixo de $2 \%$ e mudaram a cor e agregaram compostos bioativos na massa integral.

Palavras-chave: Massas integrais; Corantes naturais; Antioxidantes; Saudabilidade.

\section{Resumen}

La pasta de trigo integral es rica en fibra y antioxidantes, pero presenta un color oscuro y características de cocción alteradas. Este estudio tuvo como objetivo evaluar los efectos de los concentrados de color natural, amarillo (YNC) y rosado (PNC), en el contenido de fibra, y las propiedades tecnológicas y antioxidantes de la pasta integral fresca. Se preparó una pasta control (CP) (70:30 w:w harina de trigo integral (WGF):harina de trigo refinada (RWF)), para ser comparada a los ensayos que tuvieron YNC y PNC, en concentraciones de 1 a 2 g/100g, y WGF de 60 a 70 g/100g, siguiendo un delineamiento linear factorial $2^{2}$ con 3 puntos centrales. YNC y PNC modificaron el color de las pastas integrales sin alterar sus características tecnológicas. Las pastas amarilla (YP1, 60:40 WGF:RWF w:w, $1 \mathrm{~g} \mathrm{YNC/100} \mathrm{g)}$ y rosada (PP9, 70:30 WGF:RWF w:w, $1 \mathrm{~g}$ PNC/100 g) presentaron similares texturas, aumento de peso y pérdidas durante la cocción en comparación con $\mathrm{CP}$, por lo que fueron seleccionadas para el análisis de antioxidantes. Las tres pastas tuvieron alto contenido de fibra (por encima de $6 \mathrm{~g} / 100 \mathrm{~g}$ ), y PNC provocó un aumento significativo del contenido de fenólicos totales en la pasa integral cruda y cocida. Los concentrados de color naturales son una alternativa para modificar el color de la pasta de trigo integral al mismo tiempo que le añade un valor funcional.

Palabras clave: Pasta integral; Colorante natural; Antioxidante; Salubridad.

\section{Introduction}

Pastas are considered clean-label, given that they can be produced only with flour or semolina and water, either with bread wheat (Triticum aestivum) or hard wheat flour (Triticum durum) (Miceli et al., 2015). Pastas are considered as a source of slowly released carbohydrates. Therefore, producing a low GI (Hager et al., 2013), due to their compact structure; however, with fiber addition, they can provide a further GI reduction, as verified by Chillo et al. (2011), in durum wheat pastas with addition of up to $10 \% \beta$-glucan. Therefore, pastas can be healthier when added with wheat bran (Sobota et al., 2015) and other fiber sources, such as oat bran, psyllium, inuline (Foschia et al., 2015), and resistant starch (Aravind, Sissons, Fellows, Blazek, \& Gilbert, 2013).

With the aim of obtaining additional functional and economic benefits, pastas with whole wheat flour have gained importance, besides from presenting phytochemical compounds (Okarter et al., 2010) and fibers, they also result in economic gain, principally for countries that import wheat, since there is an increase in the use of the wheat grain external parts and germ for human consumption, which correspond to $25 \%$ of the grain (Pomeranz (Ed.), 1988).

Pastas containing fibers or whole wheat flour present different texture, cooking and color characteristics to those obtained only with bread or durum wheat flour, as seen by Aravind, Sissons, Egan, and Fellows (2012), who added separately wheat germ and bran in durum wheat pastas. The pastas with whole wheat flours presented a different color from the characteristic yellowish color of pastas.

The production of colored pastas with other ingredients addition, as spinach leafs and carrot concentrates, already exists industrially, and many researches have shown the possibilities of pastas color modification, with the addition of oregano and carrot leaf addition (Boroski et al., 2011), elderberry juice concentrate (Sun-Waterhouse, Jin, \& Waterhouse 2013), red sorghum flour (Khan, Yousif, Johnson, \& Gamlath, 2013), spiruline (Rodríguez De Marco, Steffolani, Martínez, \& León, 2014), grape power (Sant'Anna, Christiano, Marczak, Tessaro, \& Thys, 2014), and parsley leaves (Seczyk, Swieca, Gawlik-Dziki, Luty, \& Czyz, 2016). These ingredients gave colors that varied from green, red, up to purple, since the durum wheat, naturally yellowish, acquired the corresponding ingredient color, and some of them added nutritional and functional benefits to pastas. However, they are being used in concentrations that increase the dilution of the paste's gluten network.

Some problems related with the use of colored natural ingredients can be enumerated: the increase in the solids loss in the cooking water, changing its color, as happened in the obtained pastas with the addition of elderberry juice concentrate (Sun- 
Waterhouse, Jin, \& Waterhouse, 2013) and spiruline (Rodríguez De Marco, Steffolani, Martínez, \& León, 2014); and promote the dilution of gluten network, which weakens the pasta and causes a reduction in its firmness.

The present work evaluated the use of natural-colored concentrates in pastas obtained with whole wheat flour, for modifying the color of pastas, while keeping their technological properties and not interfering in the health benefits of whole wheat pastas.

\section{Methodology}

\subsection{Materials}

Whole grain wheat flour (WGF) and refined wheat flour (RWF) (Triticum aestivum) were bought from Moinho Anaconda (São Paulo, Brazil), while yellow (YNC) and pink (PNC) natural concentrates were kindly donated by GNT Brasil (São Paulo, Brazil). These concentrates are extracted by physical means and with no use of chemical additives, where YNC contains safflower, and PNC is a mixture of cherry, purple sweet potato, apple, and radish extracts. Chemical reagents for measurement of antioxidant capacity were 2,2-azinobis (3-ethyl-benzothiazoline-6-sulfonic acid) (ABTS), gallic acid, 2,2diphenyl-1-picrylhydrazyl radical (DPPH), and 6-hydroxy-2,5,7,8-tetramethylchromane-2-carboxylic acid (Trolox solution), purchased from Sigma-Aldrich, USA. Folin-Ciocalteau phenol reagent was obtained from Dinâmica (Diadema, Brazil), and methanol and ethanol were purchased from Synth (Diadema, Brazil).

\subsection{Chemical and technological analysis of raw materials}

Proximate analysis of WGF and RWF were moisture, protein (factor 5.7), ether extract, dietary fiber), and ash content, methods 46-13.01, 30-25.01, 32-07.01, 08-01.01, and 44-15.02, respectively, of the AACCI (2010). Digestible carbohydrates were calculated by difference $[=100-$ (moisture + protein + ether extract + ashes + dietary fiber)]. WGF and RWF were also analyzed for their rheological parameters by farinograph and extensigraph analysis, methods 54-21.01 and 54-10.01, respectively, of the AACCI (2010). A colorimeter Miniscan XE 3500 (Hunterlab, Reston, VI, USA) (daylight illuminant D65 and $10^{\circ}$ ) was used for measuring raw materials color ( $\mathrm{L}^{*}$, lightness; $\mathrm{a}^{*}$, redness; and $\mathrm{b}^{*}$, yellowness).

\subsection{Fresh colored whole pastas processing and evaluation}

\subsubsection{Control fresh pasta: natural color}

Control formulation (CP) fresh pasta was elaborated with WGF and RWF in the proportion of 70:30 w: w, this proportion being determined by previous tests. Flours were mixed with water (44 g/100 g flour mixture) for 15 min in a Pastaia II (capacity: $2 \mathrm{~kg}$ ) (Italvisa, Tatuí, Brazil), and left to rest for $5 \mathrm{~min}$, before extrusion of spaghetti strands (diameter: $1.8 \mathrm{~mm}$ ). Fresh pasta was hung in a drying rack for $30 \mathrm{~min}$ in a ventilated and cooled room, packed in low density polyethylene (LDPE) bags, white pigmented with 1.5\% titanium dioxide (Plastunion Indústria de Plásticos Ltda., Caieiras, Brazil), closed using a packing machine (200B, Selovac, São Paulo, Brazil), and refrigerated $\left(4^{\circ} \mathrm{C}\right)$ for 24 hours before technological analysis.

\subsubsection{Yellow and pink fresh whole wheat pastas}

Yellow pasta (YP) and pink pasta (PP) of whole wheat were formulated with addition of 1, 1.5 and $2 \%$ from colored concentrates, following a linear experimental design with axial points $(-1,+1)$, and three replicates at the central point $(0,0)$ (Table 1). Yellow pasta (YP) had independent variables WGF:RWF (X1) (which corresponds to the proportion between whole grain and refined wheat flour) and YNC (X2). Pink pasta (PP) had variables WGF:RWF(Y1) and PNC (Y2). Dependent variables were technological properties: raw and cooked color, cooked texture (cutting force), cooking loss, and weight gain. 


\subsection{Measurement of pasta chemical and technological properties}

Proximate composition of produced pasta followed the methods indicated for raw materials analysis. Technological properties included cooking test (optimal cooking time (OCT), weight gain, and solids loss) (method 66-50.01, AACC International, 2010), as well as color of raw and cooked pasta (measured as indicated previously). Color difference, $\Delta \mathrm{Eab}$, was calculated as $\Delta \mathrm{Eab}=[\Delta \mathrm{L} 2+\Delta \mathrm{a} 2+\Delta \mathrm{b} 2] 1 / 2$, where each delta corresponds to the difference in the color parameter between two samples. Texture of cooked pasta was measured with a TA.XT2 Texture Analyzer (Stable Micro Systems, Surrey, England), with a Light Knife Blade (A/LKB) probe (method 66-50.01, AACC International, 2010). Response Surface Methodology (RSM) for YP and PP was used for determination of regression coefficients, with minimal determination coefficient (R2) of 0.80 (Neto et al., 2010), followed by analysis of variance (ANOVA, $p \leq 0.05$ ), with the objective of observing the ingredients effects on pastas quality.

\subsection{Selection of colored whole wheat pastas}

For determining the pastas with similar characteristics of weight gain, solids loss and pasta cutting force to CP, a Principal Components Analysis (PCA) was done. Data from PCA was plotted in a biplot, where formulations located near CP were selected formulations for evaluation of total phenolics content (TPC) and antioxidant capacity.

\subsection{Total phenolic content (TPC) and antioxidant capacity}

Bioactive compounds in pasta were extracted by lyophilizing raw and cooked pasta (Liotop LP820, Liobras, São Carlos, Brazil), grinding and dissolving in methanol in $0.5 \mathrm{mg} / \mathrm{mL}$ concentration, then centrifuging at $4900 \mathrm{rpm}$ during $5 \mathrm{~min}$ (Baby I 206-BL, Fanem, São Paulo, Brazil). The Folin-Ciocalteau method (Roesler et al., 2007) was followed for determination of total phenolics content (TPC). Briefly, a $200 \mu \mathrm{L}$ aliquot of pasta extract was mixed with $1000 \mu \mathrm{L}$ of 10-fold diluted Folin-Ciocalteau reagent and $800 \mu \mathrm{L}$ of $7.5 \%$ sodium carbonate solution. After $5 \mathrm{~min}$ reaction at $50^{\circ} \mathrm{C}$, absorbance at $760 \mathrm{~nm}$ was read in a spectrophotometer (DU-640 ${ }^{\mathrm{TM}}$, Beckman-Coulter-Brea, CA, USA). Gallic acid (0.3125 to $50 \mu \mathrm{g} / \mathrm{mL}$ ) was used as standard, and the results are expressed as micrograms of gallic acid equivalents ( $\mu \mathrm{g} \mathrm{GAE} / \mathrm{g})$ in dry basis.

\subsection{DPPH assay of whole wheat pasta}

DPPH free radical scavenging activity analysis, adapted by Brand-Williams, Cuvelier, \& Berset (1995), was done using a standard curve with Trolox ( 25 to $200 \mu \mathrm{M}$ ). An aliquot of $100 \mu \mathrm{L}$ pasta extract (prepared as previously described) and $100 \mu \mathrm{l}$ of methanol were mixed with $1000 \mu \mathrm{L}$ of DPPH solution $(0.004 \% \mathrm{w} / \mathrm{v})$, and left for $30 \mathrm{~min}$ reaction in a dark place. The absorbance of the remaining DPPH was measured at $517 \mathrm{~nm}$ against a blank. Results are indicated as milligrams of Trolox Equivalent (TE)/g in dry basis.

\subsection{ABTS scavenging capacity of whole wheat pasta}

The radical cation ABTS scavenging capacity of whole wheat pastas was measured using the method described by Re et al. (1999). Briefly, an aliquot of $25 \mu \mathrm{L}$ pasta extract (prepared as in 2.5) and $175 \mu \mathrm{l}$ of ethanol were mixed with $1000 \mu \mathrm{L}$ of diluted ABTS solution (prepared by reacting ABTS stock solution $(7 \mathrm{mM})$ with potassium persulfate $(2.45 \mathrm{mM})$ ). Absorbance was read after 6 min at $734 \mathrm{~nm}$ against a blank. Trolox was used as standard curve (3.125 to $125 \mu \mathrm{M})$ in ethanol. Results are expressed in mg Trolox Equivalent (TE)/g in dry basis.

\subsection{Statistical analysis}

TPC and antioxidant capacity of selected pastas were evaluated by ANOVA and Tukey's multiple comparison test (p- 
value $\leq 0.05$ ). All statistical analyses were done using the software Statistica 7.0 (StatSoft, Tulsa, USA), excepting PCA, done on SAS software version 9.02 (SAS Institute, North Carolina, USA). All the analyses were performed in triplicate, except for texture cutting force of pastas that was done in quintuplicate.

\section{Results and Discussion}

\subsection{Chemical and technological analysis of raw materials}

Proximate analysis of raw materials indicated that WGF and RWF presented 9.97 and $10.90 \mathrm{~g}$ of moisture/100 g of sample, respectively. When analyzed in $100 \mathrm{~g}$ of dry basis, WGF and RWF presented $13.32 \pm 0.52$ and $12.68 \pm 0.84 \mathrm{~g}$ of protein, $1.96 \pm 0.16$ and $1.42 \pm 0.17 \mathrm{~g}$ of fat, $1.61 \pm 0.02$ and $0.68 \pm 0.02 \mathrm{~g}$ of ash, $10.38 \pm 1.31$ and $2.89 \pm 0.17 \mathrm{~g}$ of fiber, and 72.73 and $82.33 \mathrm{~g}$ of carbohydrates, respectively. Farinographic analysis indicated a higher water absorption by WGF than RWF (65.3 and $58.2 \%$, respectively), while the stability of RWF was superior to WGF (23.1 \pm 0.8 and $15.5 \pm 0.9$ minutes, respectively). Extensigraph analysis at $45 \mathrm{~min}$ showed a lower resistance to extension for WGF ( $434 \pm 28 \mathrm{BU}$ ) than for RWF ( $525 \pm 35 \mathrm{BU}$ ), as well as a lower extensibility for WGF $(105 \pm 7.5 \mathrm{~cm})$ than RWF $(125 \pm 7 \mathrm{~cm})$. These results indicate that RWF was a strong flour, given its high stability to mixture, while it presented a medium extensibility and resistance to extension, being appropriate for pasta production.

\subsection{Measurement of pasta technological properties}

Instrumental color of raw $C P$ was: $L^{*}=46.25 \pm 0.17, a^{*}=11.37 \pm 0.36$ and $b^{*}=23.43 \pm 0.73$; after cooking, $C P$ presented dark yellow color $\left(L^{*}=49.79 \pm 0.48, a^{*}=7.20 \pm 0.10, b^{*}=14.57 \pm 0.12\right)$. An optimal cooking time (OCT) of $270 \mathrm{~s}$ was determined, and used for the cooking test, where the cooked pasta showed weight gain of $92.78 \pm 5.78 \mathrm{~g} / 100 \mathrm{~g}$, solids loss of $3.95 \pm 0.16 \mathrm{~g} / 100 \mathrm{~g}$, and cutting force of $1.52 \pm 0.11 \mathrm{~N}$.

Table 1 shows the technological properties for YP and PP, which were used for the Response Surface Methodology (RSM) analysis. Table 2 and Figure 1 show the obtained the mathematical models and response surfaces for YP. The increase in the concentration of YNC (x2) increased the redness $\left(a^{*}\right)$ of raw YP, but it did not affect any other of the measured technological properties. After pasta cooking, the independent variables had no significant effects on technological properties of YP. 
Table 1. Technological properties of yellow (YP) and pink (PP) fresh whole wheat pastas ${ }^{1}$.

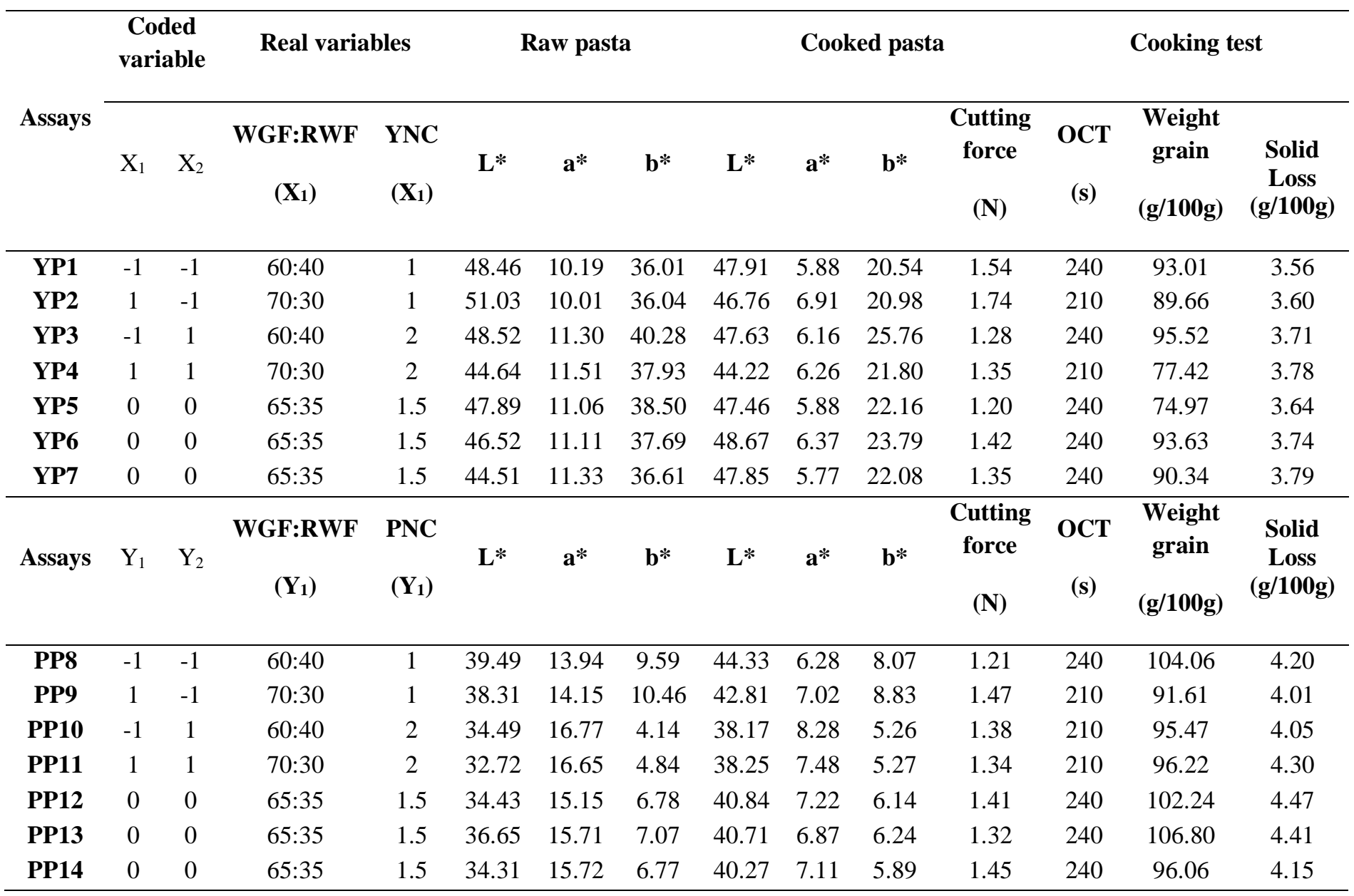

${ }^{1}$ WGF: whole grain wheat flour; RWF: refined wheat flour; YNC: yellow natural concentrate; PNC: pink natural concentrate; YP: yellow pasta; PP: pink pasta; OCT: optimal cooking time.

Source: Authors.

Figure 1. Response Surface from experimental design for color parameter a* of raw yellow fresh whole pasta (YP). x1: (-1, 0, 1) correspond to (60:40, 65:35, 70:30 WGF:RWF w:w), where WGF: whole grain wheat flour; RWF: refined wheat flour. x2: ($1,0,1)$ correspond to $(1,1.5,2 \mathrm{~g} \mathrm{YNC} / 100 \mathrm{~g}$ flour mixture), where YNC: yellow natural concentrate.

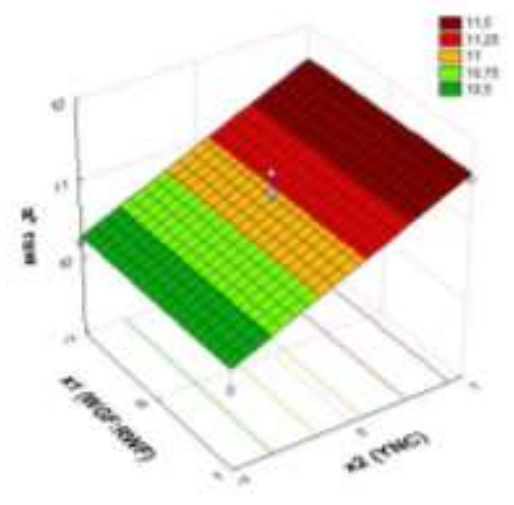

Source: Authors. 
decreased the lightness $\left(\mathrm{L}^{*}\right)$ and yellowness $\left(\mathrm{b}^{*}\right)$ of both raw and cooked pasta (Figure $2 \mathrm{a}, 2 \mathrm{c}, 2 \mathrm{~d}, 2 \mathrm{f}$ ). Figure 2e shows that the redness $\left(\mathrm{a}^{*}\right)$ of cooked PP increased with PNC increase, and simultaneously, it decreased due to the interaction between WGF:RWF and PNC (y1y2); the latter effect could be related to the brownish color of WGF. The technological properties of cutting force, weight gain, or cooking losses were not influenced by the variation in flours and colored concentrates, neither in the raw or cooked form and have values close to the control paste, showing that only the color was changed and there was no damage to the formation of the gluten network. The variation in the proportion between refined and whole wheat flour did not significantly affect the pastas characteristics, which opens up the possibility of producing pastas with varied nutrient contents, principally fibers. Both results obtained for YP and PP are quite positive, indicating that it could be possible to obtain colored pastas, with variations of YNC and PNC concentrations, with no effects on their technological properties.

Table 2. Mathematical models and averages obtained from experimental design for yellow (YP) and pink (PP) fresh whole.

Pastas.

\begin{tabular}{|c|c|c|c|c|c|c|c|c|}
\hline & \multicolumn{4}{|c|}{ Technological characteristics } & Mathematical model $^{\mathrm{a}}$ & $\mathbf{R}^{2}$ & Fcal/Ftab & p-value \\
\hline \multirow{9}{*}{$\mathbf{Y} \mathbf{P}^{\mathbf{b}}$} & \multirow{3}{*}{ Raw } & \multirow{3}{*}{\multicolumn{2}{|c|}{ Color }} & $\mathrm{L}^{*}$ & 47.37 & 0.64 & 0.19 & 0.32 \\
\hline & & & & $a^{*}$ & $a^{*}$ raw $=10.93+0.65 x_{2}$ & 0.82 & 3.43 & 0.005 \\
\hline & & & & $b^{*}$ & 37.58 & 0.68 & 1.58 & 0.02 \\
\hline & \multirow{6}{*}{ Cooked } & \multirow{3}{*}{\multicolumn{2}{|c|}{ Color }} & $\mathrm{L}^{*}$ & 47.21 & 0.68 & 0.23 & 0.27 \\
\hline & & & & $a^{*}$ & 6.18 & 0.61 & 0.17 & 0.36 \\
\hline & & & & $b^{*}$ & 22.45 & 0.48 & 0.68 & 0.09 \\
\hline & & \multicolumn{2}{|c|}{ Cutting force } & $\mathrm{N}$ & 1.41 & 0.66 & 0.21 & 0.30 \\
\hline & & \multirow{2}{*}{$\begin{array}{c}\text { Cooking } \\
\text { test }\end{array}$} & $\begin{array}{c}\text { Weight } \\
\text { gain }\end{array}$ & $\mathrm{g} / 100 \mathrm{~g}$ & 87.79 & 0.48 & 0.10 & 0.53 \\
\hline & & & Solids loss & $\mathrm{g} / 100 \mathrm{~g}$ & 3.69 & 0.61 & 0.17 & 0.36 \\
\hline \multirow{9}{*}{$\mathbf{P P}^{\mathbf{c}}$} & \multirow{3}{*}{ Raw } & \multirow{3}{*}{\multicolumn{2}{|c|}{ Color }} & $\mathrm{L}^{*}$ & $\mathrm{~L} *(\mathrm{raw})=35.77-2.65 \mathrm{y}_{2}$ & 0.78 & 2.68 & 0.01 \\
\hline & & & & $\mathrm{a}^{*}$ & $\mathrm{a} *(\mathrm{raw})=15.44+1.33 \mathrm{y}_{2}$ & 0.97 & 19.05 & $<0.001$ \\
\hline & & & & $\mathrm{b}^{*}$ & $\mathrm{~b}^{*}(\mathrm{raw})=7.09-2.77 \mathrm{y}_{2}$ & 0.99 & 25.01 & $<0.001$ \\
\hline & \multirow{6}{*}{ Cooked } & \multirow{3}{*}{\multicolumn{2}{|c|}{ Color }} & $\mathrm{L}^{*}$ & $\mathrm{~L} *($ cooked $)=40.77-2.68 \mathrm{y}_{2}$ & 0.99 & 14.79 & $<0.001$ \\
\hline & & & & $\mathrm{a}^{*}$ & $\mathrm{a} *($ cooked $)=7.18+0.62 * \mathrm{y} 2-0.39 \mathrm{y}_{1} \mathrm{y}_{2}$ & 0.94 & 4.70 & 0.003 \\
\hline & & & & $b^{*}$ & $\mathrm{~b}^{*}($ cooked $)=6.53-1.59 \mathrm{y}_{2}$ & 0.88 & 5.60 & 0.002 \\
\hline & & \multicolumn{2}{|c|}{ Cutting force } & $\mathrm{N}$ & 1.37 & 0.71 & 0.26 & 0.25 \\
\hline & & \multirow{2}{*}{$\begin{array}{c}\text { Cooking } \\
\text { test }\end{array}$} & $\begin{array}{c}\text { Weight } \\
\text { gain }\end{array}$ & $\mathrm{g} / 100 \mathrm{~g}$ & 98.92 & 0.45 & 0.09 & 0.56 \\
\hline & & & Solids loss & $\mathrm{g} / 100 \mathrm{~g}$ & 4.23 & 0.31 & 0.05 & 0.74 \\
\hline
\end{tabular}

${ }^{\mathrm{a}}$ When model was not significant, an average value is presented. ${ }^{\mathrm{b}} \mathrm{YP}$ : yellow pasta, ${ }^{\mathrm{c} P P}$ : pink pasta $\mathrm{x}_{1}:(-1,0,1)$ correspond to $(60: 40,65: 35$, 70:30 WGF:RWF w:w), where WGF: whole grain wheat flour; RWF: refined wheat flour $\mathrm{x}_{2}:(-1,0,1)$ correspond to $(1,1.5,2 \mathrm{~g}$ YNC/100 g flour mixture), where YNC: yellow natural concentrate $\mathrm{y}_{1}:(-1,0,1)$ correspond to $\left(60: 40,65: 35,70: 30\right.$ WGF:RWF w:w) $\mathrm{y}_{2}:(-1,0,1)$ correspond to (1, 1.5, $2 \mathrm{~g}$ PNC/100 g flour mixture), where PNC: pink natural concentrate

Source: Authors.

\subsection{Selection of colored whole wheat pastas}

PCA was done to select pastas with similar properties to CP. Figure 3 shows the result from PCA done for all 15 formulations. While principal component 1 (PC1) explains $58.53 \%$ of the correlation between the analyzed properties, PC2 presented 33.02\%, which in sum explain 91.55\% of the correlation between properties. Encircled pastas CP, YP1, and PP9, located near to the control, presented more similar technological characteristics (texture, weight gain and solids loss), which 
means they would behave homogeneously when cooked together. Even though YP6 was also located near to CP, it was not chosen because it was a central point from the experimental design $(0,0)$, but its replicates did not present good repeatability (YP5 and YP7).

\subsection{Proximate composition and antioxidant capacity of CP, YP1 and PP9}

The three selected pastas (CP, YP1, and PP9) presented in average $30.13 \mathrm{~g}$ of moisture/100 $\mathrm{g}$. When compared between them, in dry basis, the three pastas presented no significant differences, with $13.74 \mathrm{~g}$ of protein, $0.85 \mathrm{~g}$ of fat, and $7.09 \mathrm{~g}$ of fiber in $100 \mathrm{~g}$ sample. Due to the fact that YP1 had a lower proportion of WGF than CP and PP9, it presented, in dry basis, a significantly lower ash content $(\mathrm{p} \leq 0.05)(1.81 \pm 0.07 \mathrm{~g} / 100 \mathrm{~g})$, in comparison to CP $(1.94 \pm 0.03 \mathrm{~g} / 100 \mathrm{~g})$, and PP9 (1.89 \pm 0.02 $\mathrm{g} / 100 \mathrm{~g}$ ). This occurred because the highest percentages of minerals are found in the outer parts of the grain, hat is, in the bran present at the WGF (Doblado-Maldonado et al., 2012).

Figure 2. Response surfaces from experimental design for pink fresh whole pasta (PP). a) Color L* for raw PP; b) Color a* for raw PP; c) Color b* for raw PP; d) Color L* for cooked PP; e) Color a* for cooked PP; f) Color b* for cooked PP y1: (-1, 0, 1) correspond to (60:40, 65:35, 70:30 WGF:RWF w:w), where WGF: whole grain wheat flour; RWF: refined wheat flour y2: (-1, $0,1)$ correspond to $(1,1.5,2 \mathrm{~g}$ PNC/100 g flour mixture), where PNC: pink natural concentrate.
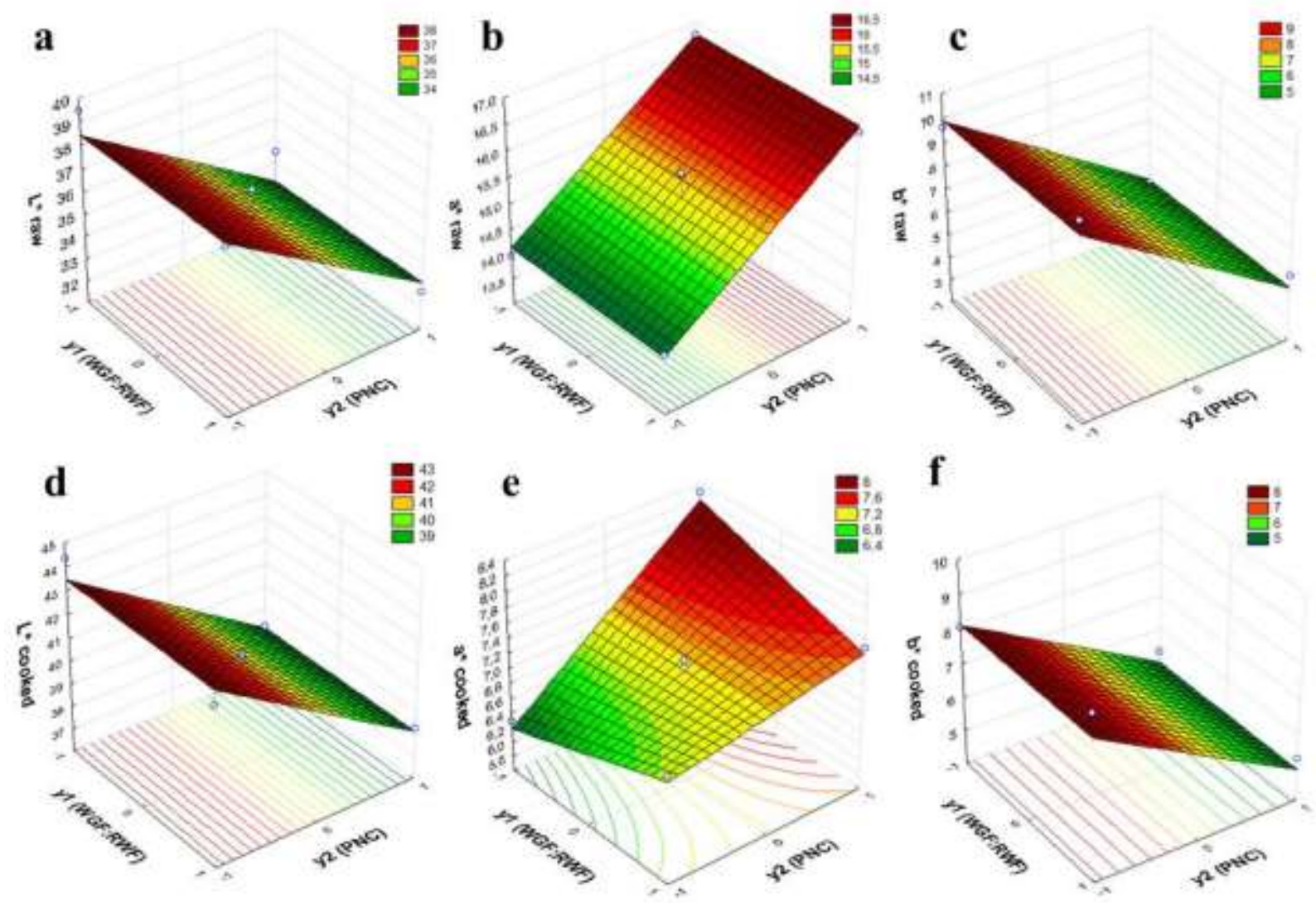

Source: Authors.

Sobota, Rzedzicki, Zarzycki, and Kuzawinska (2015) also obtained significantly higher ash content in pasta production with $40 \%$ of common wheat bran and $60 \%$ of durum wheat $(1.39 \pm 0.02 \mathrm{~g} / 100 \mathrm{~g})$, in comparison to pasta with $20 \%$ of common wheat bran and $80 \%$ of durum wheat $(1.11 \pm 0.01 \mathrm{~g} / 100 \mathrm{~g})$. It was expected that the three pastas contain higher fiber content than refined wheat pasta, as the values reported by the USDA Agricultural Research Service (2015), where cooked refined wheat 
spaghetti contains $1.8 \mathrm{~g}$ of fiber $/ 100 \mathrm{~g}$, while cooked whole wheat spaghetti has $3.9 \mathrm{~g}$ of fiber/100 g. The three selected pastas presented brownish (CP), yellowish (YP1) and pink color (PP9). Color measurements indicated big differences to control: $\Delta$ Eab of raw YP1 and PP9 with respect to CP were 12.82 and 15.47, respectively, while $\triangle E a b$ of cooked YP1 and PP9 with respect to CP decreased to 6.40 and 9.03, still presenting clear differences to the human eye, which perceives differences when values of $\Delta \mathrm{E} * \mathrm{ab}>2.3$ (Sharma, 2003). We further analyzed antioxidant activity of the pastas, for evaluating the effect of the naturalcolored concentrates on this property of whole wheat pasta.

Figure 3. Principal components analysis of the pastas (Where $\mathbf{O}=\mathrm{CP} ; \diamond=\mathrm{YP} 1$ to $7 ; \square=\mathrm{PP} 8$ to 14 ). Formulations encircled correspond to: CP: Control pasta 70:30 WGF:RWF w:w; YP1:yellow pasta (60:40 WGF:RWF w:w, $1 \mathrm{~g}$ YNC/100 g flour mixture); PP9: pink pasta (70:30 WGF:RWF w:w, $1 \mathrm{~g}$ PNC/100 g flour mixture).

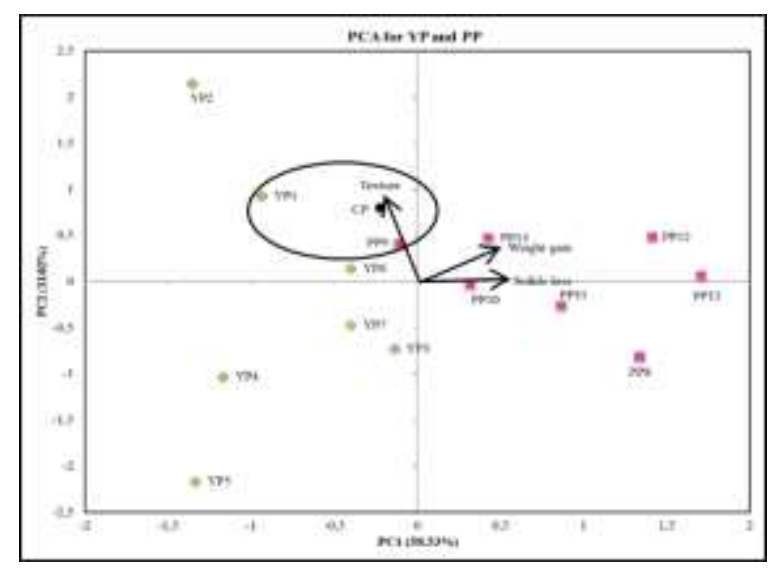

Source: Authors.

Figure 4 shows the pastas antioxidant capacities, observing that $\mathrm{CP}$ presented similar values to the other pastas. This is due to the use of WGF, which, according to Adom, Sorrells, and Liu (2005), presents naturally a higher TPC than RWF (662.86 vs. $185.50 \mu \mathrm{mol}$ of gallic acid equiv./100 g), as well as hydrophilic antioxidant activity ( $2.48 \mathrm{vs} 0.58 \mu \mathrm{mol}$ of vitamin C equiv/g) and lipophilic antioxidant activity (594.24 vs. $55.00 \mathrm{nmol}$ of vitamin E equiv/g).

Figure 4, letter A, shows that the total phenolics content (TPC) of PP9 was significantly higher ( $\leq \leq 0.05)$ than CP and YP1, both in raw and cooked pasta (raw PP9: $121.28 \mu \mathrm{g} \mathrm{GAE} / \mathrm{g} \mathrm{db}$, cooked PP9: $104.03 \mu \mathrm{g} \mathrm{GAE} / \mathrm{g} \mathrm{db}$ ). The increase of TPC due to the use of colored ingredients in pastas was also confirmed by Khan et al. (2013), who determined a TPC value of $1.88 \pm$ $0.11 \mathrm{mg} \mathrm{GAE} / \mathrm{g} \mathrm{db}$, in uncooked durum wheat pasta containing $20 \%$ of red sorghum flour, in comparison to $0.77 \pm 0.07 \mathrm{mg}$ $\mathrm{GAE} / \mathrm{g}$ of TPC in uncooked durum wheat pasta. The cooking process caused no significant variation ( $\mathrm{p} \leq 0.05$ ) of TPC content for CP and YP1, while it was significant for PP9 decreasing 14.22\%. As seen, the addition of PNC caused a significantly higher TPC in PP9 even with a concentration as low as $1 \%$. This could be caused by the natural components present in it (apple, purple sweet potato, radish and cherry), all known for their antioxidant properties. Figure 4, letter B, indicates that DPPH scavenging capacity of the three pastas presented no significant difference between them, neither in the raw nor cooked form; furthermore, there was no significant decrease $(\mathrm{p} \leq 0.05)$ in this capacity after cooking for all pastas. Figure 4 , letter $\mathrm{C}$, shows that ABTS scavenging capacity presented a similar trend to the DPPH test, being not significantly different for the three pastas, both in the raw and cooked form ( $\mathrm{p} \leq 0.05)$; the cooking process caused a significant reduction in this capacity for CP and PP9 (49.85 and $32.35 \%$, respectively), being not significant for YP1. We observed that the addition of YNC may increase the antioxidant capacity of whole wheat pasta, to the same levels than 70\% of WGF may do, given that YP1 contains only 60\% of WGF, while CP and PP9 had 70\% WGF in their formulation. Furthermore, YNC may have protected antioxidant compounds present in whole 
wheat pasta, as the cooking process did not significantly affect the results of YP1, obtaining in the three cases high antioxidant capacity retention.

Figure 4. Antioxidant analysis of fresh raw and cooked whole pastas (dry basis): A) Total phenolics content (TPC), B) DPPH and C) ABTS antioxidant capacities. Formulations correspond to: CP: control pasta (70:30 WGF:RWF w:w); YP1: yellow pasta (60:40 WGF:RWF w:w, $1 \mathrm{~g}$ YNC/100 g flour mixture); PP9: pink pasta (70:30 WGF:RWF w:w, $1 \mathrm{~g}$ PNC/100 g flour mixture). Columns with different letters (upper (raw pasta) or lower case (cooked pasta)) in the same graph differ significantly (pvalue $\leq 0.05)$. N.S. not significant $/ *$ indicates significant difference between raw and cooked values $(\mathrm{p} \leq 0.05)$.
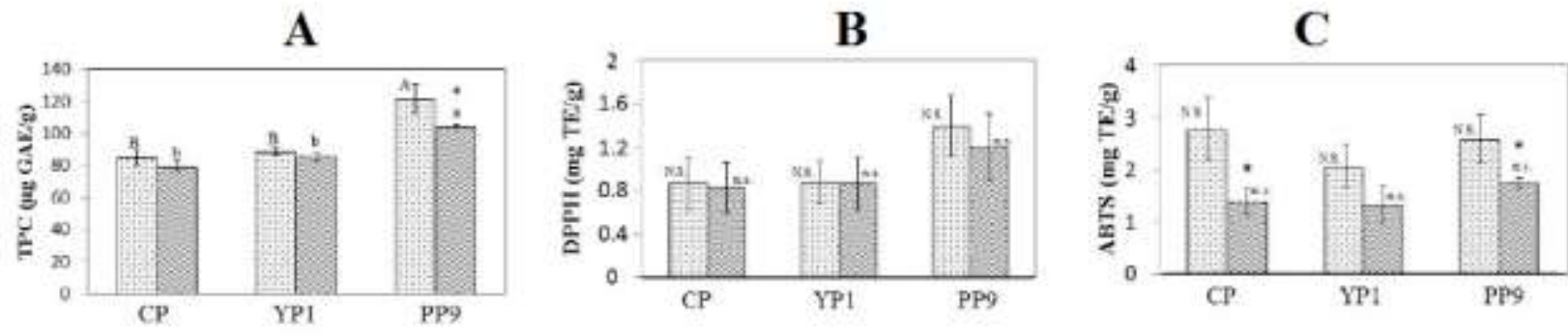

\section{¿ Raw pasta Cooked pasta}

Source: Authors.

\section{Conclusion}

This work used reduced concentrations of natural-colored concentrates, which promoted the color change, contributed to the bioactive compounds, and without the need for the addition of artificial colorants to adjust the product's color. The use of natural-colored concentrates in concentrations below $2 \%$ was viable for producing whole wheat pasta, containing different colors and functional bioactive, and maintaining the whole wheat pasta's technological and antioxidant properties. This study showed that it was possible to diversify whole wheat pastes, maintaining the appeal of this product's clean label and healthiness.

\section{Acknowledgments}

Authors thank the Conselho Nacional de Desenvolvimento Científico e Tecnológico (CNPq) for the scholarship for Adriana Lucia Wahanik, Fundação de apoio ao ensino, pesquisa e extensão (FAEPEX) from UNICAMP, and Mario Sikita, from GNT Brasil, for kindly providing samples of natural concentrates for this study. We also thank Nathanny Alves, Nayara Castro and Igor Borges for their valuable help at the experimental stage.

\section{References}

AACCI. (2010). Approved Methods of Analysis. AACC International.

Adom, K. K., Sorrells, M. E., \& Liu, R. H. (2005). Phytochemicals and antioxidant activity of milled fractions of different wheat varieties. Journal of Agricultural and Food Chemistry, 53(6), 2297-2306. https://doi.org/10.1021/jf048456d

Aravind, N., Sissons, M., Egan, N., \& Fellows, C. (2012). Effect of insoluble dietary fibre addition on technological, sensory, and structural properties of durum wheat spaghetti. Food Chemistry, 130(2), 299-309. https://doi.org/10.1016/j.foodchem.2011.07.042

Aravind, N., Sissons, M., Fellows, C. M., Blazek, J., \& Gilbert, E. P. (2013). Optimisation of resistant starch II and III levels in durum whe at pasta to reduce in vitro digestibility while maintaining processing and sensory characteristics. Food Chemistry, 136(2), 1100-1109. https://doi.org/10.1016/j.foodchem.2012.08.035

Boroski, M., Aguiar, A., Boeing, J., Rotta, E., Wibby, C., Bonafé, E., Souza, N., \& Visentainer, J. (2011). Enhancement of pa sta antioxidant activity with oregano and carrot leaf. Food Chemistry, 125(2), 696-700. https://doi.org/10.1016/j.foodchem.2010.09.068 
Research, Society and Development, v. 10, n. 3, e7110312072, 2021

(CC BY 4.0) | ISSN 2525-3409 | DOI: http://dx.doi.org/10.33448/rsd-v10i3.13072

Brand-Williams, W., Cuvelier, M. E., \& Berset, C. (1995). Use of a free radical method to evaluate antioxidant activity. LWT - Food Science and Technology, 28(1), 25-30. https://doi.org/10.1016/S0023-6438(95)80008-5

Chillo, S., Ranawana, D. V, \& Henry, C. J. K. (2011). Effect of two barley b-glucan concentrates on in vitro glycaemic impact and cooking quality of spaghetti. LWT - Food Science and Technology, 44(4), 940-948. https://doi.org/10.1016/j.1wt.2010.11.022

Doblado-Maldonado, A. F., Pike, O. A., Sweley, J. C., \& Rose, D. J. (2012). Key issues and challenges in whole wheat flour milling and storage. Journal of Cereal Science, 56(2), 119-126. https://doi.org/10.1016/j.jcs.2012.02.015

Foschia, M., Peressini, D., Sensidoni, A., Brennan, M. A., \& Brennan, C. S. (2015). How combinations of dietary fibres can affect physicochemical characteristics of pasta. LWT - Food Science and Technology, 61(1), 41-46. https://doi.org/10.1016/j.lwt.2014.11.010

Hager, A. S., Czerny, M., Bez, J., Zannini, E., \& Arendt, E. K. (2013). Starch properties, in vitro digestibility and sensory evaluation of fresh egg pasta produced from oat, teff and wheat flour. J. Cereal Sci., 58, 156-163.

Khan, I., Yousif, A., Johnson, S. K., \& Gamlath, S. (2013). Effect of sorghum flour addition on resistant starch content, phenolic profile and antioxidant capacity of durum wheat pasta. Food Research International, 54(1), 578-586. https://doi.org/10.1016/j.foodres.2013.07.059

Miceli, A., Francesca, N., Moschetti, G., \& Settanni, L. (2015). The influence of addition of Borago officinalis with antibacterial activity on the sensory quality of fresh pasta. International Journal of Gastronomy and Food Science, 2(2), 93-97. https://doi.org/10.1016/j.ijgfs.2014.12.004

Neto, B. B., Scarminio, I. S., \& Bruns, R. E. (2010). Como fazer experimentos: Pesquisa e desenvolvimento na Ciência e na Indústria. Bookman.

Okarter, N., Liu, C.-S., Sorrells, M. E., \& Liu, R. H. (2010). Phytochemical content and antioxidant activity of six diverse varieties of whole wheat. Food Chemistry, 119(1), 249-257. https://doi.org/10.1016/j.foodchem.2009.06.021

Pomeranz (Ed.), Y. (1988). Wheat: Chemistry and Technology (3rd ed.). AACC.

Re, R., Pellegrini, N., Proteggente, A., Pannala, A., Yang, M., \& Rice-Evans, C. (1998). Antioxidant activity applying an improved ABTS radical cation decolorization assay. Free Radical Biology \& Medicine, 26(98), 1231-1237.

Rodríguez De Marco, E., Steffolani, M. E., Martínez, C. S., \& León, A. E. (2014). Effects of spirulina biomass on the technological and nutritional quality of bread wheat pasta. LWT - Food Science and Technology, 58, 102-108. https://doi.org/10.1016/j.lwt.2014.02.054

Roesler, R., Carrasco, L. C., Holanda, R. B., Alves, C., Sousa, S., \& Pastore, G. M. (2007). Atividade antioxidante de frutas do cerrado. Ciênc. Tecnol. Aliment., 27(1), 53-60.

Sant'Anna, V., Christiano, F. D. P., Marczak, L. D. F., Tessaro, I. C., \& Thys, R. C. S. (2014). The effect of the incorporation of grape marc powder in fettuccini pasta properties. LWT - Food Science and Technology, 58, 497-501. https://doi.org/10.1016/j.lwt.2014.04.008

Seczyk, L., Swieca, M., Gawlik-Dziki, U., Luty, M., \& Czyz, J. (2016). Effect of fortification with parsley (Petroselinum crispum Mill.) leaves on the nutraceutical and nutritional quality of wheat pasta. Food Chemistry, 190, 419-428. https://doi.org/10.1016/j.foodchem.2015.05.110

Sharma, G. (Ed.). (2003). Digital color imaging handbook. CRC Press.

Sobota, A., Rzedzicki, Z., Zarzycki, P., \& Kuzawinska, E. (2015). Application of common wheat bran for the industrial production of high-fibre pasta. International Journal of Food Science and Technology, 50, 111-119. https://doi.org/10.1111/ijfs.12641

Sun-Waterhouse, D., Jin, D., \& Waterhouse, G. I. N. (2013). Effect of adding elderberry juice concentrate on the quality attributes, polyphenol contents and antioxidant activity of three fibre-enriched pastas. Food Research International, 54(1), 781-789. https://doi.org/10.1016/j.foodres.2013.08.035

USDA Agricultural Research Service, N. D. L. (2015). USDA National Nutrient Database for Standard Reference, Release 28. 